\title{
The Influence of Leadership Style, Career Development and Work Environment to Employee Engagement at PT Indo Japan Steel Center
}

\author{
Faiz Irsyad Prasetyo \\ Student of Magister Management, Mercubuana University \\ Jakarta, Indonesia
}

\begin{abstract}
The purpose of this study was to determine the influence of Leadership Style, Career Development, and Work Environment on Employee Engagement at PT Indo Japan Steel Center. The population in this study were 86 people. The sampling used a purposive sampling method. Data collection techniques with questionnaires. Data analysis used instrument validity, reliability, classic assumption tests, multiple linear regression analysis, and correlations between dimensions. Hypothesis testing uses the F-Test, t-Test, and the Determination Coefficient using SPSS version 21. The results of the analysis show that the Leadership Style partially has a positive and significant effect on Employee Engagement. Career Development partially has a positive and significant effect on Employee Engagement. Work Environment partially has a positive and significant effect on Employee Engagement. The Leadership Style, Career Development, and Work Environment simultaneously influence the Employee Engagement of $64.8 \%$ and the remaining $35.2 \%$ by other variables.
\end{abstract}

Keywords:- Leadership Style, Career Development, Work Environment, Employee Engagement.

\section{INTRODUCTION}

Engaged employees will be motivated to increase their productivity, willing to accept challenges and feel that their work is meaningful to themselves. This will have a positive impact on productivity and organizational growth. Engagement has 3 (three) dimensions namely (1) cognitive, shown by the existence of trust and support for the objectives and values of the organization, (2) affective, shown by a sense of ownership, pride and attachment to the organization, and the third (3) behavior is shown by the willingness to work hard and the desire to stay within the organization (Balducci 2010: 143).

According to Kahn (Naidoo and Martins 2014: 433), Employee Engagement is defined as manifestation and expression of an individual's ideal self in task behaviors that encourage a connection to work with others, a connection to personal presence in the company, showing how much employees identify themselves with their work and emotional commitment to their work. However, in reality,

\author{
Charles Bohlen Purba \\ Lecturer of Postgraduate, Mercubuana University \\ Jakarta, Indonesia
}

there are a number of things related to employee engagement that did not go as expected at PT Indo Japan Steel Center.

The object of this research is a company that produces steel plates and sheets, which mostly focuses on automotive steel production, through the vision and mission of PT Indo Japan Steel Center, capturing market demands and giving the best solutions by providing high quality products to maximize customer satisfaction with active participation from all employees.

In its business, the company emphasizes consistent quality in every aspect of work, improving products and quality, on time and quick service for customers. The numerous targets owned by PT Indo Japan Steel Center must be balanced with the number of employees they have, but in reality, the number of employees they have is imbalanced with the number of employees who contribute to the company. The following are the percentage $(\%)$ of employee engagement types at PT Indo Japan Steel Center from 2017 to 2018 , formulated based on the following table:

\begin{tabular}{|c|c|c|}
\hline TYPE & $\begin{array}{c}\mathbf{2 0 1 7} \\
\text { (86 Employees) }\end{array}$ & $\begin{array}{c}\mathbf{2 0 1 8} \\
\text { (86 Employees) }\end{array}$ \\
\hline ENGAGED & $44 \%$ & $42 \%$ \\
\hline NOT ENGAGED & $50 \%$ & $56 \%$ \\
\hline ACTIVELY DISENGAGED & $6 \%$ & $2 \%$ \\
\hline TOTAL & $\mathbf{1 0 0 \%}$ & $\mathbf{1 0 0 \%}$ \\
\hline
\end{tabular}

Table 1:- Percentage of employee engagement types Source: Human Resources in 2019

Based on table 1 above, it shows that the level of engagement at PT Indo Japan Steel Center from 2017 to 2018 was still not well implemented. At the level of Engaged, it has decreased from $44 \%$ to $42 \%$, which means a reduction in employees who have totality at work, whereas the Actively Disengaged type decreased from $6 \%$ to $2 \%$ due to termination of employees who did not contribute, but that does not signify that the company has been running well, because the Not Engaged type increased from 50\% to 56\%, which is a factor causing the diminishing employee engagement towards the company. 
This term was popularized by Gallup the Consulting Organization in Winowoda (2018:40) saying that engaged is the highest level of employee attachment to the company. This type of employees will tend to always show high and maximum performance in completing every job assigned to them, whereas Not Engaged shall mean they do not feel too "engaged" to their work, meaning that employees only work according to their portion and what the organization pays to them, and Actively Disengaged is a type of employees who are not attached to the organization. They openly show sentiment of unhappiness and dissatisfaction with their work.

\begin{tabular}{|c|c|c|c|}
\hline Year & $\begin{array}{c}\text { No. of employees } \\
\text { by the end of the } \\
\text { year }\end{array}$ & $\begin{array}{c}\text { No. of resigned } \\
\text { employees in a } \\
\text { year }\end{array}$ & $\begin{array}{c}\text { Turnover } \\
\text { Rate }\end{array}$ \\
\hline 2016 & 82 & 4 & $4.6 \%$ \\
\hline 2017 & 86 & 6 & $7.1 \%$ \\
\hline 2018 & 86 & 7 & $8.1 \%$ \\
\hline
\end{tabular}

Table 2:- Percentage of employee turnover rate Source: Human Resources in 2019

Based on Table 2, it shows that in 2016 the turnover rate at PT Indo Japan Steel Center reached $4.6 \%$, while in 2017 it increased to $7.1 \%$ and in 2018 it increased to $8.1 \%$. The increase in turnover every year creates problems for the company and identifies the weak level of employee engagement in the company. One indicator of the emergence of employee turnover is marked by the emergence of feeling lazy, wanting to find another job, the desire to leave the organization, positive behavior is different, violating the rules, increasing absence and the emerging thoughts to leave. According to Harnoto (Sukwadi \& Milkha 2014:1) turnover is the tendency or intensity of individuals to leave the organization for various reasons, including the desire to get a better job.

In an effort to suppress high employee turnover, the company can formulate and implement policies that can attract employees to continue working and serving (Luthfi 2017:10). Companies having employees with high work engagement can provide benefits or advantages for the company, because it can reduce their intention to leave the company, increase productivity, profitability, growth and customer satisfaction. According to Schaufeli and Bakker in Winowoda D.A (2018: 39) that employee engagement is a positive and happy state of mind about work, marked by vigor, dedication and absorption. Therefore, there needs to be a change in human resource management at PT Indo Japan Steel Center in order to achieve employee engagement.

The researchers collected data based on the results of previous studies that showed which factors may influence employee engagement, based on theories and literatures. The researchers tried to conduct preliminary research by surveying / distributing questionnaires to 30 employees at PT Indo Japan Steel Center. The Pre-Survey results conducted on 30 employees are as follows:

$>$ Culture $27 \%$

$>$ Compensation $47 \%$
Work Environment 53\%

Career Development 63\%

$>$ Internal Communication $30 \%$

$>$ Health \& Safety $17 \%$

$>$ Leadership Style 63\%

Based on the background and the results of this preresearch data conducted there obtained 3 (three) factors that most influenced on the employee engagement in the PT Indo Japan Steel Center, The three factors are the most answers, namely Leadership Style by 63\%, Career Development by $63 \%$, and Work Environment by $53 \%$. The researchers are interested and wanted to conduct research on " the influence of leadership style, career development and work environment to employee engagement at pt indo japan steel center ".

\section{LITERATURE REVIEW}

\section{A. Leadership Style}

Leadership Style cannot be separated from followership because leadership is meaningless without influence and followers. According to Rohmat (2010:58), the leadership style consists of four (4) things, namely:

$>$ Participative Leadership Style

$>$ Autocratic leadership style

$>$ Laissez-Faire Leadership Style

$>$ Transformational Leadership Style

\section{B. Career Development}

According to Widodo (2015:114), career is the overall function or job position of a person in the organization, and career goals are the highest position someone will occupy in an organization. According to Handoko (2012:123), career development is concerned with efforts to increase one's personal experience and ability to achieve his/her career plan or process through which one chooses career goals and career paths. According to Rivai in Widodo (2015:113), career development is the process of increasing individual work skills achieved in order to reach the desired career. According to Rivai (2014: 213), the factors that influence career development are as follows:

$>$ Job performance

$>$ Exposure

$>$ Networking

$>$ Loyalty to the organization

$>$ Counselors and sponsors

$>$ Opportunity to grow

\section{Work environment}

The work environment is anything that is around workers that can affect themselves in carrying out their assigned tasks. According Sedarmayanti (2011:26), in general, there are 2 (two) types of work environment, namely: Physical Work Environment is all physical forms that are located around the workplace that can affect employees either directly or indirectly. Non-physical Work Environment is all conditions that occur related to work relationships, both relationships with superiors and fellow co-workers, or relationships with subordinates. 
According Sedarmayanti (2011:28), there are several factors that can affect the formation of a physical work environment conditions associated with the ability of humans / employees, including:

$>$ Lighting / Light at work.

$>$ Workplace Temperature

$>$ Workplace humidity.

$>$ Air circulation at workplace.

$>$ Workplace noise.

$>$ Mechanical vibrations at workplace.

$>$ Smell at workplace.

$>$ Color coordination at workplace.

$>$ Workplace decoration.

$>$ Music and security at work

\section{Employee Engagement}

Employee engagement is one of the human capital factors that will lead to success if it can be managed consistently well. According to Schiemann (2011:30), he defines engagement (attachment) as the energy or motivation of employees to help the organization achieve its goals. Engagement can also be interpreted as contributions arising from employees to strive to complete their works seriously in the interests of organizational success.

According to Schaufeli \& Bakker (2004: 4), there are 3 indicators of employee engagement:

$>$ Vigor is an employee engagement shown through physical and mental strength when doing work.

$>$ Dedication is the emotional attachment of employees to their work. Dedication illustrates the enthusiasm of employees at work, proud of the work done and of the company where he works, remain inspired and perseverance to the end at the company without feeling threatened by the challenges faced.

$>$ Absorption is an employee engagement which is illustrated by employee behavior that gives full attention to his work.

\section{E. Conceptual Framework}

Based on this theory, a model of the relationship among variables is illustrated as shown in Figure 1

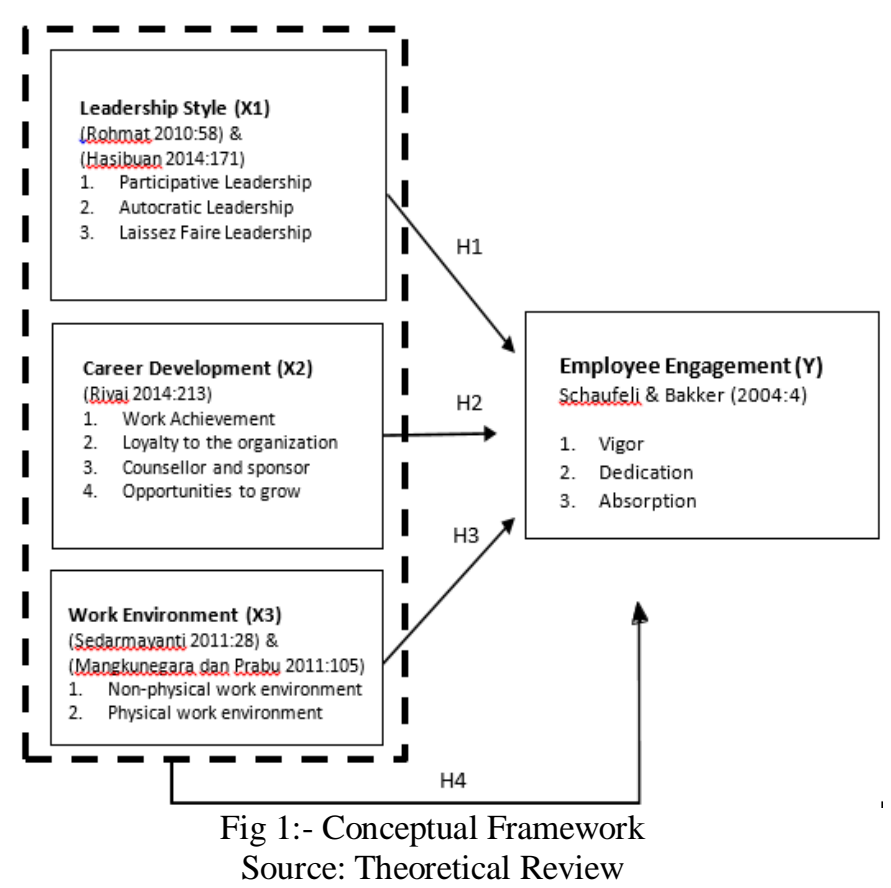

\section{F. Hypothesis}

Based on the framework and a number of previous studies above, a number of hypotheses to be tested in this study are as follows:

$>$ H1: Leadership Style significantly influences the engagement of PT Indo Japan Steel Center employees.

$>$ H2: Career development significantly affects the engagement of PT Indo Japan Steel Center employees.

$>$ H3: Work environment significantly influences the engagement of PT Indo Japan Steel Center employees.

$>$ H4: Leadership Style, Career Development and work environment altogether have a significant effect on employee engagement at PT Indo Japan Steel Center.

\section{RESEARCH METHODOLOGY}

Based on the conceptual framework, the purpose of this study was to get an understanding about the influence of leadership style, career development and work environment to employee engagement. An operational definition parameter is with measure and examine variables, dimensions, and indicators as shown in table 3 :

\begin{tabular}{|c|c|c|c|c|c|}
\hline Variables & \multicolumn{2}{|c|}{ Dimension } & Indicator & $\begin{array}{l}\text { Questionnaire } \\
\text { Number }\end{array}$ & Scale Design \\
\hline \multirow[t]{2}{*}{$\begin{array}{c}\text { Leadership } \\
\text { Style (Rohmat } \\
\text { 2010:58) \& } \\
\text { (Hasibuan } \\
\text { 2014:171) }\end{array}$} & & Autocratic & $\begin{array}{l}\text { - } \\
\text { Delegation of tasks is } \\
\text { very strict and disciplined } \\
\text { Settlement of conflicts by } \\
\text { punishment } \\
\text { No coordination in } \\
\text { decision making }\end{array}$ & $\begin{array}{l}1 \\
2 \\
3\end{array}$ & $\begin{array}{l}\text { Ordinal } \\
\text { Ordinal } \\
\text { Ordinal }\end{array}$ \\
\hline & & Participative & $\begin{array}{lc}- & \text { Joint effort to formulate } \\
\text { an objective } \\
\text { - } \quad \text { Willing to accept } \\
\text { suggestions and criticisms } \\
\text { Listening to inputs before } \\
\text { action }\end{array}$ & $\begin{array}{l}4 \\
5 \\
6\end{array}$ & $\begin{array}{l}\text { Ordinal } \\
\text { Ordinal } \\
\text { Ordinal }\end{array}$ \\
\hline
\end{tabular}


ISSN No:-2456-2165

\begin{tabular}{|c|c|c|c|c|}
\hline & 3. Laissez-Faire & $\begin{array}{l}\text { Give full responsibility in } \\
\text { problem solving } \\
\text { Express feelings when } \\
\text { dislike or encounter a problem } \\
\text { - } \quad \text { Consult about a serious } \\
\text { problem if it cannot be solved as a } \\
\text { group or team. }\end{array}$ & $\begin{array}{l}7 \\
8 \\
9\end{array}$ & $\begin{array}{l}\text { Ordinal } \\
\text { Ordinal } \\
\text { Ordinal }\end{array}$ \\
\hline & 4. Transformational & $\begin{array}{l}\text { Wise in making decisions } \\
\text { Provide very clear } \\
\text { delegation } \\
\text { Openly accepts opinions } \\
\text { from employees }\end{array}$ & $\begin{array}{l}10 \\
11 \\
12\end{array}$ & $\begin{array}{l}\text { Ordinal } \\
\text { Ordinal } \\
\text { Ordinal }\end{array}$ \\
\hline \multirow[t]{4}{*}{$\begin{array}{l}\text { Career development } \\
\text { (Rivai 2014:213) }\end{array}$} & $\begin{array}{l}\text { 1. Work } \\
\text { Achievement }\end{array}$ & $\begin{array}{l}\text { Outstanding employees } \\
\text { are highly valued } \\
\text { Career opportunities are } \\
\text { always provided } \\
\text { Job performance in line } \\
\text { with competency standards }\end{array}$ & $\begin{array}{l}13 \\
14 \\
15\end{array}$ & $\begin{array}{l}\text { Ordinal } \\
\text { Ordinal } \\
\text { Ordinal }\end{array}$ \\
\hline & $\begin{array}{l}\text { Loyalty to } \\
\text { organization }\end{array}$ & $\begin{array}{l}\text { Loyalty to the company } \\
\text { Willing to sacrifice } \\
\text { Not taking any outside } \\
\text { offer }\end{array}$ & $\begin{array}{l}16 \\
17 \\
18\end{array}$ & $\begin{array}{l}\text { Ordinal } \\
\text { Ordinal } \\
\text { Ordinal }\end{array}$ \\
\hline & $\begin{array}{l}\text { 3. Counsellor and } \\
\text { sponsor }\end{array}$ & $\begin{array}{l}\text { Career coaching/ } \\
\text { counseling } \\
\text { Support for education and } \\
\text { training } \\
\text { Always be given } \\
\text { guidance/direction }\end{array}$ & $\begin{array}{l}19 \\
20 \\
21\end{array}$ & $\begin{array}{l}\text { Ordinal } \\
\text { Ordinal } \\
\text { Ordinal }\end{array}$ \\
\hline & $\begin{array}{l}\text { Opportunities to } \\
\text { grow }\end{array}$ & $\begin{array}{l}\text { Open opportunity for } \\
\text { growth } \\
\text { - } \quad \text { Give opportunity to } \\
\text { continue to higher education } \\
\text { - } \quad \text { Give permission to } \\
\text { continue education outside } \\
\text { working hours }\end{array}$ & $\begin{array}{l}22 \\
23 \\
24\end{array}$ & $\begin{array}{l}\text { Ordinal } \\
\text { Ordinal } \\
\text { Ordinal }\end{array}$ \\
\hline \multirow[t]{2}{*}{$\begin{array}{l}\text { Work environment } \\
\text { (Sedar mayanti } \\
\text { 2011:28) \& } \\
\text { (Mangkunegara \& } \\
\text { Prabu (2011:105) }\end{array}$} & $\begin{array}{l}\text { 1. Physical Work } \\
\text { Environment }\end{array}$ & $\begin{array}{ccc} & \bullet & \text { Lighting } \\
- & & \text { Air circulation } \\
\bullet & \text { Cleanliness } \\
& \bullet & \text { Noise } \\
& \bullet & \text { Security } \\
\text { - } & & \text { Work equipment } \\
\end{array}$ & $\begin{array}{l}25 \\
26 \\
27 \\
28 \\
29 \\
30\end{array}$ & $\begin{array}{l}\text { Ordinal } \\
\text { Ordinal } \\
\text { Ordinal } \\
\text { Ordinal } \\
\text { Ordinal } \\
\text { Ordinal }\end{array}$ \\
\hline & $\begin{array}{l}\text { 2. Non-Physical } \\
\text { Work Environment }\end{array}$ & 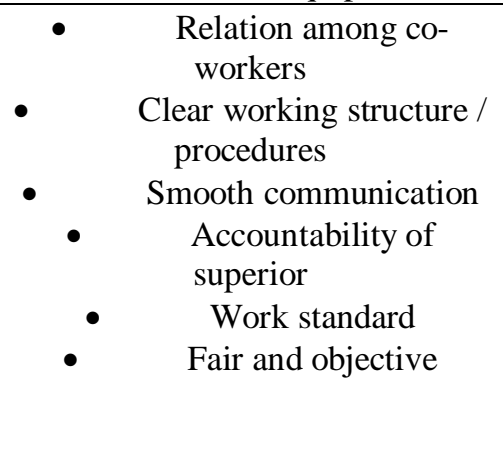 & $\begin{array}{l}31 \\
32 \\
33 \\
34 \\
35 \\
36\end{array}$ & $\begin{array}{l}\text { Ordinal } \\
\text { Ordinal } \\
\text { Ordinal } \\
\text { Ordinal } \\
\text { Ordinal } \\
\text { Ordinal }\end{array}$ \\
\hline
\end{tabular}


ISSN No:-2456-2165

\begin{tabular}{|c|c|c|c|c|c|c|}
\hline $\begin{array}{c}\text { Employee } \\
\text { engagement } \\
\text { (Schaufeli \& Bakker } \\
\text { 2004:4) }\end{array}$ & 1 & Vigor & & $\begin{array}{l}\text { Having high energy } \\
\text { Giving the best effort } \\
\text { Survival despite } \\
\text { difficulties }\end{array}$ & $\begin{array}{l}37 \\
38 \\
39\end{array}$ & $\begin{array}{l}\text { Ordinal } \\
\text { Ordinal } \\
\text { Ordinal }\end{array}$ \\
\hline & & Dedication & & $\begin{array}{l}\text { Having enthusiasm } \\
\text { Giving inspiration } \\
\text { examples } \\
\text { Feeling proud at work }\end{array}$ & $\begin{array}{l}40 \\
41 \\
42\end{array}$ & $\begin{array}{l}\text { Ordinal } \\
\text { Ordinal } \\
\text { Ordinal }\end{array}$ \\
\hline & & Absorption & $\begin{array}{l}\bullet \\
\bullet \\
\bullet\end{array}$ & $\begin{array}{l}\text { Full concentration at } \\
\text { work } \\
\text { Happy to be engaged in } \\
\text { working } \\
\text { Feeling time flies when } \\
\quad \text { working }\end{array}$ & $\begin{array}{l}43 \\
44\end{array}$ & $\begin{array}{l}\text { Ordinal } \\
\text { Ordinal } \\
\text { Ordinal }\end{array}$ \\
\hline
\end{tabular}

Table 3:- Operational Definition

Source Theoretical Review

\section{A. Type of Research Design}

This research method uses a quantitative approach and a descriptive method that is a method for solving problems by exposing or describing the research results as is. This study uses quantitative explanatory and causal methods that will test the hypothesis about the effect of one or several independent variables on the dependent variable.

\section{B. Research variables}

The research variables to be observed are leadership style, career development, work environment as an independent variable and as the dependent variable is employee engagement.

\section{Population and Sample}

In line with the research focus, the population in this study were employees of PT Indo Japan Steel Center totaling 93 employees. The sampling technique in this study was purposive sampling. The sampling in this study were 86 employees excluding the Board of Directors and Board of Commissioners.

\section{Types, Sources and Techniques of Data collection}

The data of this study are primary data collected by questionnaire distribution techniques, namely by giving written statements to respondents. Secondary data in this study were obtained by studying reference books and a number of other literatures. Data were collected through a closed questionnaire and conducted a validity reliability test. Statistical Product and Service Solutions (SPSS) 21 computer software is used for data analysis purposes. The research instruments are arranged in a number of statements and answer choices using a Likert scale, consisting of: "Strongly Agree" (score 5), "Agree" with (score 4), "Quite Agree" with (score 3), "Disagree" with (score 2), and "Strongly Disagree" with (score 1). For questions that use negative sentences, adjustments are made.

\section{E. Data Analysis Method}

Data analysis was performed to test the research instruments, the classic assumption test, and the multiple linear regression analysis test, hypothesis testing, correlation analysis between dimensions. This study uses Multiple Linear Regression analysis then the data are processed using SPSS Version 21.

\section{RESULTS AND DISCUSSION}

Overview of respondents' characteristics and research variables are in table 4

\begin{tabular}{|c|c|c|c|}
\hline \multicolumn{2}{|c|}{ Characteristics Description } & Total & $\begin{array}{c}\text { Percentage } \\
(\%)\end{array}$ \\
\hline \multirow{2}{*}{ Gender } & Male & 73 & 85 \\
& Female & 13 & 15 \\
\hline \multirow{4}{*}{ Age } & $<25$ & 30 & 35 \\
& $26-35$ & 22 & 26 \\
& $36-45$ & 20 & 23 \\
Recent & $>45$ & 14 & 16 \\
Education & High School / Vocational & 53 & 62 \\
& School / Similar & 8 & 9 \\
& Diploma & 23 & 27 \\
& S1 / Bachelor & 2 & 2 \\
\hline \multirow{5}{*}{ Work } & < Master & & \\
term & 2 - 5 years & 26 & 30 \\
& $6-10$ years & 54 & 63 \\
& $>10$ years & 6 & 7 \\
& & 0 & 0 \\
\hline
\end{tabular}

Table 4:- Respondent characteristics

Source Theoretical Review

\section{Characteristic of Respondents}

As shown in table 4, the highest number of respondents is male gender as many as 73 or $85 \%$ and female as many as 13 people or $15 \%$ in filling out the questionnaire of this research. The productive age who 
filled this questionnaire was 52 people with a percentage of $61 \%$, whereas old or unproductive age is 34 people with a percentage of $39 \%$. The most age in filling out the questionnaire is in the age range of $<20$ years.

\section{Testing Classic Assumption Research Instruments}

The highest number of recent education is High School / Vocational School which has 53 people with a percentage of $62 \%$. Then the highest tenure of PT Indo Japan Steel Center employees is in working period of 5-10 years with 54 people with a percentage of $63 \%$

\begin{tabular}{|c|c|c|c|c|}
\hline Dimension & Indicator & r count & r table & Info \\
\hline \multirow{3}{*}{$\begin{array}{l}\text { Leadership Style Autocratic } \\
\text { (X1) }\end{array}$} & $\mathrm{X} 1.1$ & 0,740 & 0.209 & Valid \\
\hline & $\mathrm{X} 1.2$ & 0,756 & 0.209 & Valid \\
\hline & $\mathrm{X} 1.3$ & 0,648 & 0.209 & Valid \\
\hline \multirow[t]{3}{*}{ Leadership Style Participativ } & $\mathrm{X} 1.4$ & 0,678 & 0.209 & Valid \\
\hline & $\mathrm{X} 1.5$ & 0,717 & 0.209 & Valid \\
\hline & $\mathrm{X} 1.6$ & 0,748 & 0.209 & Valid \\
\hline \multirow[t]{3}{*}{ Leadership Style Laissez-Faire } & $\mathrm{X} 1.7$ & 0,748 & 0.209 & Valid \\
\hline & $\mathrm{X} 1.8$ & 0,792 & 0.209 & Valid \\
\hline & XI.9 & 0,858 & 0.209 & Valid \\
\hline \multirow[t]{3}{*}{ Leadership Style Transformational } & X.10 & 0,794 & 0.209 & Valid \\
\hline & $\mathrm{X} .11$ & 0,626 & 0.209 & Valid \\
\hline & X.12 & 0,790 & 0.209 & Valid \\
\hline \multirow{3}{*}{$\begin{array}{l}\text { Work Achievement } \\
\text { (X2) }\end{array}$} & $\mathrm{X} 2.1$ & 0,761 & 0.209 & Valid \\
\hline & $\mathrm{X} 2.2$ & 0,777 & 0.209 & Valid \\
\hline & $\mathrm{X} 2.3$ & 0,686 & 0.209 & Valid \\
\hline \multirow[t]{3}{*}{ Loyalty to organization } & $\mathrm{X} 2.4$ & 0,794 & 0.209 & Valid \\
\hline & $\mathrm{X} 2.5$ & 0,844 & 0.209 & Valid \\
\hline & $\mathrm{X} 2.6$ & 0,880 & 0.209 & Valid \\
\hline \multirow[t]{3}{*}{ Counsellor and sponsor } & $\mathrm{X} 2.7$ & 0,849 & 0.209 & Valid \\
\hline & $\mathrm{X} 2.8$ & 0,864 & 0.209 & Valid \\
\hline & $\mathrm{X} 2.9$ & 0,917 & 0.209 & Valid \\
\hline \multirow[t]{3}{*}{ Opportunities to grow } & $\mathrm{X} 2.10$ & 0,892 & 0.209 & Valid \\
\hline & $\mathrm{X} 2.11$ & 0,622 & 0.209 & Valid \\
\hline & $\mathrm{X} 2.12$ & 0,764 & 0.209 & Valid \\
\hline \multirow{6}{*}{$\begin{array}{l}\text { Physical Work Environment } \\
\text { (X3) }\end{array}$} & $\mathrm{X} 3.1$ & 0,818 & 0.209 & Valid \\
\hline & X3.2 & 0,458 & 0.209 & Valid \\
\hline & X3.3 & 0,744 & 0.209 & Valid \\
\hline & X3.4 & 0,815 & 0.209 & Valid \\
\hline & $\mathrm{X} 3.5$ & 0,785 & 0.209 & Valid \\
\hline & X3.6 & 0,720 & 0.209 & Valid \\
\hline \multirow[t]{6}{*}{ Non-Physical Work Environment } & X3.7 & 0,752 & 0.209 & Valid \\
\hline & X3.8 & 0,710 & 0.209 & Valid \\
\hline & X3.9 & 0,713 & 0.209 & Valid \\
\hline & $\mathrm{X} 3.10$ & 0,639 & 0.209 & Valid \\
\hline & X3.11 & 0,690 & 0.209 & Valid \\
\hline & $\mathrm{X} 3.12$ & 0,656 & 0.209 & Valid \\
\hline \multirow{3}{*}{$\begin{array}{l}\text { Vigor } \\
(\mathbf{Y})\end{array}$} & Y.1 & 0,679 & 0.209 & Valid \\
\hline & Y.2 & 0,841 & 0.209 & Valid \\
\hline & Y.3 & 0,787 & 0.209 & Valid \\
\hline \multirow[t]{3}{*}{ Dedication } & Y.4 & 0,744 & 0.209 & Valid \\
\hline & Y.5 & 0,763 & 0.209 & Valid \\
\hline & Y.6 & 0,847 & 0.209 & Valid \\
\hline \multirow[t]{3}{*}{ Absorption } & Y.7 & 0,682 & 0.209 & Valid \\
\hline & Y.8 & 0,770 & 0.209 & Valid \\
\hline & Y.9 & 0,800 & 0.209 & Valid \\
\hline
\end{tabular}

Table 5:- Validity Test

Source: Analysis with SPSS version 21 
ISSN No:-2456-2165

\begin{tabular}{|c|c|c|c|}
\hline Variable & Cronbach Alpha & Terms & Info \\
\hline Leadership Style & 0.924 & 0.60 & Reliabel \\
\hline Career Development & 0.949 & 0.60 & Reliabel \\
\hline Work Environment & 0.910 & 0.60 & Reliabel \\
\hline Employee Engagement & 0.912 & 0.60 & Reliabel \\
\hline
\end{tabular}

Table 6:- Reliability Test

Source: Analysis with SPSS version 21

From the validity and reliability test results on all items, the four statement variables are declared valid and reliable. Similarly, the classic assumption test consisting of the Kolmogorof normality test, the heterodixity test and the multicollinearity test meet the classic assumptions. In other words, the regression equation obtained meets the provisions of the Best Linear Unlimited Estimator (BLUE).

\section{Normality Test}

The normality test aims to test whether the regression model, confounding or residual variables have a normal distribution. In the basis of the decision making Kolgomorov-Smirnov test (K-S test) is to see the probability with the provisions, the probability 0.05 then $\mathrm{Ha}$ is rejected and Ho is accepted. Results from the Figure 2 It is known that the data is normally distributed. Can be seen with the spread of the points that touch and spread on the diagonal lines in the picture and spread along the diagonal lines.

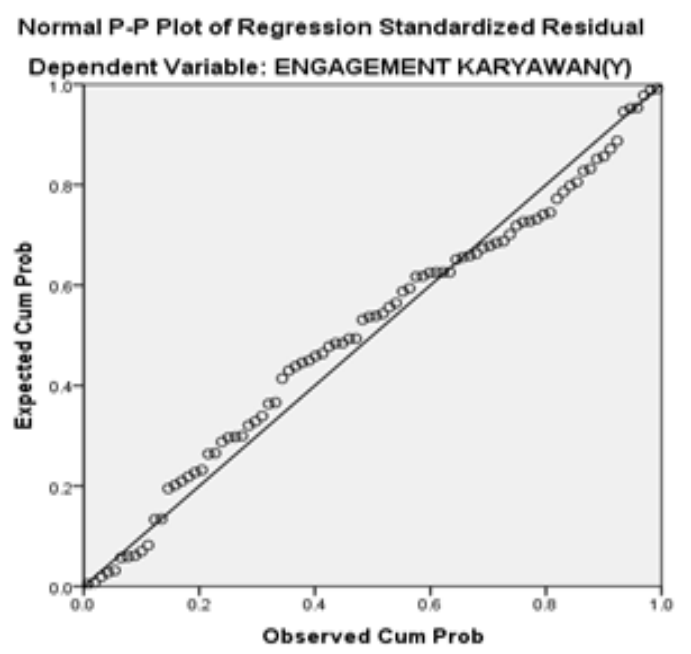

Fig 2:- Normality Test

Source: Analysis with SPSS version 21

\section{Multicollinearity Test}

Multicollinearity test aims to test whether the regression model found a correlation between independent variables in this research

\begin{tabular}{|c|c|c|}
\hline \multicolumn{3}{|c|}{ Coefficients } \\
\hline \multirow{2}{*}{ Model } & Collinearity Statistics \\
\cline { 2 - 3 } & Tolerance & VIF \\
\hline (Constant) & & 2.285 \\
\hline Leadership Style & 0.438 & 5.921 \\
\hline $\begin{array}{c}\text { Career } \\
\text { Development }\end{array}$ & 0.169 & \\
\hline $\begin{array}{c}\text { Work } \\
\text { Environment }\end{array}$ & 0.214 & 4.677 \\
\hline
\end{tabular}

Table 7:- Multicollinearity Test Source: Analysis with SPSS version 21

Results from table 7 The tolerance value of each independent variable has a tolerance value $>0.10$ and a VIF value $<10$, this means that there is no multicollinearity between the Leadership Style, Career development and Work Environment variables used in the regression model.

\section{Heteroscedasticity Test}

The heteroscedasticity test is aims to test whether in the regression model there is an unequal variance from the residuals of one observation to another. To detect whether a variable occurs heteroscedasticity or cannot be seen with a certain pattern on a scatterplot graph where the $\mathrm{X}$ axis is the predicted $\mathrm{Y}$ and the $\mathrm{X}$ axis is the standardized (Y-predicted Y-true) residual. The result of Figure 3 states that the points on the scatterplots graph do not form a clear pattern and the points are spread evenly randomly above and below the number 0 on the $\mathrm{Y}$ axis.

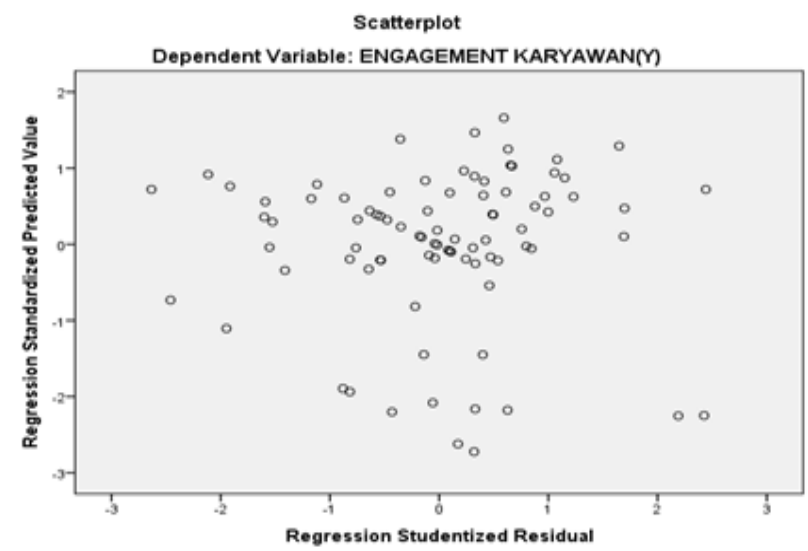

Fig 3:- Heteroscedasticity Test

Source: Analysis with SPSS version 21 
Multiple Linear Regression Analysis Test

\begin{tabular}{|c|c|c|c|c|c|c|}
\hline \multicolumn{7}{|c|}{ Coefficientsa } \\
\hline \multirow{2}{*}{\multicolumn{2}{|c|}{ Model }} & \multicolumn{2}{|c|}{$\begin{array}{l}\text { Unstandardized } \\
\text { Coefficients }\end{array}$} & \multirow{2}{*}{$\begin{array}{c}\text { Standardized } \\
\text { Coefficients } \\
\text { Beta }\end{array}$} & \multirow[b]{2}{*}{$\mathrm{T}$} & \multirow[b]{2}{*}{ Sig. } \\
\hline & & $\mathrm{B}$ & Std. Error & & & \\
\hline \multirow[t]{4}{*}{1} & (Constant) & 5,025 & 2,450 & & 2,052 & 0,043 \\
\hline & Leadership Style & 0,181 & 0,079 & 0,223 & 2,288 & 0,025 \\
\hline & Career Development & 0,215 & 0,099 & 0,340 & 2,172 & 0,033 \\
\hline & Work Environment & 0,222 & 0,098 & 0,314 & 2,259 & 0,027 \\
\hline
\end{tabular}

Table 8:- Multiple Linear Regression Analysis Tes

Source: Analysis with SPSS version 21 follows:

Based on Table 8 the regression equation formed is as

$\mathrm{Y}=5.025+0.181 \mathrm{X} 1+0.215 \mathrm{X} 2+0.222 \mathrm{X} 3+\mathrm{e}$

Description:

$\mathrm{Y}=$ Employee Engagement

$\mathrm{X} 1$ = Leadership Style

$\mathrm{X} 2$ = Career Development

$\mathrm{X} 3=$ Work Environment

From this equation it can be explained that:

- A constant of 5.025 means that if the Leadership Style (X1), Career Development (X2), and Work Environment (X3) has a value of 0, then the Employee Engagement (Y) at PT Indo Japan Steel Center has a value of 5.025. The positive value constant means that employee engagement will increase with the influence of the variables of Leadership Style, Career Development and Work Environment.

- The regression coefficient of the Leadership Style variable gives a value of 0.181 which means that if the leadership style variable is getting better with the assumption that other variables are fixed then the Engagement of employees at PT Indo Japan Steel Center will increase by 0.181 . This shows the leadership style contributes positively to employee engagement, so the higher the role of the Leadership Style the higher employee engagement at PT Indo Japan Steel Center.

- The Career Development variable regression coefficient gives a value of 0.215 which means that if the career development variable is getting better with the assumption that other variables remain then the employee engagement at PT Indo Japan Steel Center will increase by 0.215 . This shows that career development positively contributes to employee engagement, so the higher career development the higher employee engagement at PT Indo Japan Steel Center.

- The regression coefficient of the work environment variable gives a value of 0.222 which means that if the work environment variable is getting better with the assumption that other variables remain then the employee engagement at PT Indo Japan Steel Center will increase by 0.222 . This shows that the work environment contributes positively to employee engagement, so the higher the work environment the higher employee engagement at PT Indo Japan Steel Center.

\section{Determination Coefficient Test (R2)}

Determination coefficient is used to measure the extent of the model's ability to explain the dependent variable or the magnitude that shows the amount of variation of the dependent variable that can be explained by the independent variable.

\begin{tabular}{|c|c|c|c|c|}
\hline \multicolumn{5}{|c|}{ Model Summary $^{\text {b }}$} \\
\hline Model & R & R Square & $\begin{array}{c}\text { Adjusted R } \\
\text { Square }\end{array}$ & $\begin{array}{c}\text { Std. Error of } \\
\text { the Estimate }\end{array}$ \\
\hline 1 & $.813^{\mathrm{a}}$ & 0.661 & 0.648 & 3.82000 \\
\hline
\end{tabular}

Table 9:- Determination Coefficient Test

Source: Analysis with SPSS version 21

Based on table 9 above, the magnitude of the determination coefficient which is known in the $\mathrm{R}$ square is 0.661 or $66.1 \%$. This shows the percentage contributed by the influence of independent variables namely leadership style, career development and work environment on employee engagement of $66.1 \%$, or the variation of independent variables used in the model is able to explain the $66.1 \%$ of the dependent variable variation and the rest $(33.9 \%)$ is influenced by other variables not included in this research model, for examples work culture, compensation, internal communications, occupational safety and health, work stress, motivation and others.

\section{Simultaneous Test (F Test)}

The results of the $\mathrm{F}$ test contained the calculated $\mathrm{F}$ value of $53,185>\mathrm{F}$ value of the table 2,717 .or by seeing the significance of 0.000 , far below the 0.05 probability value, then statistically against the sample tested, very strong evidence was obtained that the independent variables (leadership style, career development and work environment) together has a positive and significant effect on employee engagement. 


\begin{tabular}{|c|c|c|c|c|}
\hline \multicolumn{5}{|c|}{ ANOVA $^{\mathbf{a}}$} \\
\hline Model & & df & F & Sig. \\
\hline 1 & Regression & 3 & 53,185 &, $000^{\mathrm{b}}$ \\
\hline & Resudual & 82 & & \\
\hline & Total & 85 & & \\
\hline
\end{tabular}

Table 10:- Simultaneous Test

Source: Analysis with SPSS version 21

\section{Statistical Test ( $t$ Test)}

Based on the data table 10 can be explained as follows:

- The influence of leadership style on employee engagement is positive and significant. The calculated value of $t$ is greater than the value of the table that is $2.288>1.663(\alpha=5 \%, \mathrm{df}=86)$ the significance value of $0.025<0.05$, then Ho is rejected and Ha is accepted.

- Effect of Career Development on positive and significant employee engagement. $\mathrm{T}$ value greater than
$2.172>$ t table value $1.663(\alpha=5 \%, \mathrm{df}=86)$ significance value of $0.033<0.05$, then $\mathrm{Ho}$ is rejected and $\mathrm{Ha}$ is accepted.

- The influence of the Work Environment on employee engagement is positive and significant. $\mathrm{T}$ value greater than 2.259> $1.663(\alpha=5 \%, \mathrm{df}=86)$ significance value of $0.027<0.05$, then Ho is rejected and Ha is accepted.

\section{Correlation among Dimensions}

This correlation test between dimensions used in research intends to test the strongest relationship on the variables of leadership style, career development, and work environment on employee engagement. The closeness in the relationship of this variable is expressed in the form of a correlation coefficient, if the correlation is above 0.5 can be seen in table 11 .

\begin{tabular}{|c|c|c|c|c|}
\hline & & \multicolumn{3}{|c|}{ Engagement Karyawan (Y) } \\
\hline \multirow[t]{2}{*}{ Variable } & Dimension & Vigor & Dedication & Absorption \\
\hline & & Y1 & $\mathrm{Y} 2$ & Y3 \\
\hline \multirow[t]{4}{*}{ Leadership Style (X1) } & Autocratic (X1.1) & $\mathbf{0 , 4 8 2}$ & 0,605 & 0,575 \\
\hline & Participativ (X1.2) & 0,529 & 0,608 & 0,586 \\
\hline & Laissez-Faire (X1.3) & 0,537 & $\mathbf{0 , 6 2 9}$ & 0,626 \\
\hline & Transformational (X1.4) & 0,471 & 0,590 & 0,533 \\
\hline \multirow{4}{*}{$\begin{array}{c}\text { Career Development } \\
\text { (X2) }\end{array}$} & Work Achievement (X2.1) & 0,680 & $\mathbf{0 , 7 8 0}$ & 0,765 \\
\hline & Loyalty to organization (X2.2) & 0,631 & 0,725 & 0,711 \\
\hline & Counsellor and sponsor (X2.3) & 0,519 & 0,650 & 0,657 \\
\hline & Opportunities to grow (X2.4) & 0,477 & 0,644 & 0,643 \\
\hline \multirow[t]{2}{*}{ Work Environment (X3) } & Physical Work Environment (X3.1) & 0,624 & 0,775 & $\mathbf{0 , 7 8 9}$ \\
\hline & Non Physical Work Environment (X3.2) & 0,553 & $\mathbf{0 , 5 3 4}$ & 0,570 \\
\hline
\end{tabular}

Table 11:- Correlation among Dimension Test

Source: Analysis with SPSS version 21

Based on table 11 which has interpreted the coefficient can be concluded that:

In the leadership style variable, the strong supportive dimension is the dimension of Laissez-Faire (X1.3) towards employee involvement in dedication (Y2), because it has a coefficient value of 0.629 . This explains the laissez-faire leadership style that is needed for the employees of PT Indo Japan Steel Center in making a strong dedication. While the value in the autocratic dimension (X1.1) towards employee involvement in the vigor dimension (Y1), because it has a coefficient of 0.482 . This explains the autocratic leadership style only provides relationships that are influencing the vigor dimension.

In the career development variable, the strong dimension is the dimension of work performance (X2.1) towards employee involvement in dedication (Y2), because it has a coefficient value of 0.780 . This explains about career development in achieving enormous achievements for PT Indo Japan Steel Center employees to create strong dedication. While the value that exists in the dimension of opportunity to grow (X2.4) to employee involvement in the vigor dimension (Y1), because it has a coefficient of 0.477 . This explains career development in growth opportunities, only providing a relationship that is in the process of increasing vigor.

In the work environment variable, the strong dimension of the relationship is the dimension of the physical work environment (X3.1) to employee engagement on the absorption dimension (Y3), because it has a coefficient value of 0.789 . This explains that the physical work environment is indispensable for the employees of PT Indo Japan Steel Center in creating a strong dimension of absorption. While the value that is contained in the dimensions of the non-physical work environment (X3.2) on employee engagement on the dimension of dedication (Y2), because it has a coefficient of 0.534 . This explains that nonphysical work environments only provide relationships that are currently affecting the vigor dimension. 


\section{CONCLUSIONS AND SUGGESTIONS}

\section{A. Conclusions}

This study aims at examining the influence of leadership style, career development and work environment on employee engagement at PT. Indo Japan Steel Center. Based on the results of research conducted, the following are conclusions from the research:

$>$ Leadership Style has a partially and significantly positive effect on PT Indo Japan Steel Center Employee engagement. The dimensions of Laissez-Faire leadership style affect the dimensions of "engagement dedication". The leadership style is adapted to the expertise and abilities of subordinates, which can increase the company engagement and productivity.

$>$ Career Development has a partially and significantly positive effect on PT Indo Japan Steel Center employee engagement. The dimensions of "career development" in work performance affect the dimensions of "engagement dedication". Career development is carried out to the maximum, employees who have performed well need to be appreciated and career opportunities should always be given to those who excel in order to create engagement and increasing company productivity.

> Work Environment has a partially and significantly positive effect on the engagement of PT Indo Japan Steel Center employees. Dimensions of the "physical work environment" affect the dimensions of "engagement absorption". The physical and nonphysical work environment must be done well so that employees would feel comfortable at work and able to increase employee engagement.

- Leadership style, career development and work environment altogether have a significant influence on employee engagement whereas the influence of independent variables on dependent ones accounts $64.8 \%$, or the variation of independent variables used in this regression model is able to explain $64.8 \%$ of the variation of dependent variable (Engagement). Meanwhile, the remaining $35.2 \%$ is influenced by other factors outside the tested variables, such as work culture, compensation, internal communications, occupational safety and health, work stress, motivation and others. Managing human resources in the company is determined by the employees' job performance or productivity in completing their duties and responsibilities as workers, but all of that will not be realized if the employees do not have a high engagement towards the company.

Based on the research results and conclusions in this study, the following are some suggestions, among others:

$>$ Applying the leadership style on the employees of PT Indo Japan Steel Center should be adjusted to subordinates' expertise and abilities in order that absorption in the delegation can be well received. Leadership styles such as giving full confidence to subordinates, assuming that employees are competent in carrying out tasks and only offer help at subordinates' request, should be done in such a way that employees can have a sense of confidence and pride in their abilities to subsequently do the work well and thus, foster employee engagement.

$>$ For career development variables, the company should provide a maximum career to each of its employees. Career development must be fair and balanced based on the employees' achievements. In addition, measuring work performance must be based on existing work competencies so that employees would feel fair in doing their work and motivated in increasing their productivity, and creating employee engagement.

$>$ Work environment, both physical and non-physical, should be implemented properly. The existence of a physical environment such as getting adequate lighting, good air circulation in the room, well-maintained cleanliness, low risk of noise, making beautiful decorations and adequate work equipment, should be carried out properly. In addition, working relations between leaders and subordinates must be harmonious, smooth communication must be maintained and relations among colleagues should be done fairly and objectively, work responsibilities must be in accordance with their respective positions. This should be created in a good company culture and all employees would be able to apply this culture. Indirectly, this can increase employee engagement and have an impact on employee work productivity.

$>$ For other researchers, they are expected to be able to continue similar research and to develop the concept of engagement and that the number of populations do not account at just one place in order to generalize better. In addition, further research may be made more comprehensively on employee engagement beyond the factors studied.

\section{REFERENCES}

[1]. Balducci, C., Franco Fraccaroli., dan Wilmar. B Schaufeli. (2010). Psychometric properties of the Italian version of the Utrecht Work Engagement Scale (UWES-9): A Crosscultural Analysis. European Journal of Psychological Assessment, 26(2), 143-149.

[2]. Handoko, T. H. (2012). Manajemen Personalia dan Sumber Daya Manusia. Yogyakarta: BPFE.

[3]. Hasibuan, Malayu S.P. (2016). Manajemen Sumber Daya Manusia. Edisi Revisi. Jakarta: Penerbit PT Bumi Aksara.

[4]. Luthfi Mahfudi H. (2017). Pengaruh Budaya Organisasi, Kepemimpinan, dan Kompensasi Terhadap Employee Engagement di PT Asuransi Jasa Indonesia. Jurnal SWOT, Volume VII, No 1.

[5]. Mangkunegara, A.A., dan Prabu, A., (2011). Manajemen Sumber Daya Manusia Perusahaan. Bandung: PT Remaja Rosdakarya.

[6]. Naidoo, P dan N. Martins. (2014). Investigating the Relationship between Organizational Culture and Work Engagement. Problems and Perspectives in Management, Volume 12, Issue 4.

[7]. Rivai, V. (2014). Kepemimpinan dan Perilaku Organisasi. Jakarta: Raja Grafindo Persada. 
[8]. Rivai, V. (2014). Manajemen Sumber Daya Manusia untuk Perusahaan dari Teori ke Praktek. Depok: PT. Rajagrafindo Persada

[9]. Rohmat, (2010). Kepemimpinan Pendidikan Konsep dan Aplikasi. STAIN Press. Purwokerto.

[10]. Schaufeli, W.B. dan Bakker, A.B. (2010). Defining and Measuring Work Engagement: Bringing Clarity to the Concept" in Bakker, A.B. and Leiter, M.P. (Eds), Work Engagement: A Handbook of Essential Theory and Research, Psychology Press, Hove, NY, pp. 10-24

[11]. Sedarmayanti. (2011). Tata Kerja dan Produktivitas Kerja. Bandung: Mandar Maju

[12]. Sukwadi \& Milkha (2014). Faktor-Faktor yang Mempengaruhi Kinerja dan Turnover Intention Karyawan Usaha Kecil Menengah. Jurnal rekayasa Sistem Industri Vol 3 (1)

[13]. Widodo, Eko S. (2015). Manajemen Pengembangan Sumber Daya Manusia. Yogyakarta: Penerbit Pustaka Pelajar

[14]. Winowoda D.A (2018). Pengaruh Employee Engagement dan Kepuasan Kerja terhadap Kinerja Karyawan Melalui Komitmen Organisasi Sebagai Variabel Intervening di Hotel Grand Inna Malioboro Yogyakarta. Skripsi. Universitas Islam Indonesia. Yogyakarta 